\title{
Klasifikasi Citra Histopatologi Kanker Payudara menggunakan Data Resampling Random dan Residual Network
}

\author{
Wahyudi Setiawan \\ Jurusan Teknik Informatika, Fakultas Teknik, Universitas Trunojoyo Madura \\ Jl Raya Telang, PO BOX 2, Kamal, Bangkalan, Jawa Timur 69162 \\ Naskah Diterima : 10 April 2021; Diterima Publikasi : 8 Juni 2021
}

DOI: 10.21456/voll1iss1pp70-77

\begin{abstract}
Data imbalance between classes is one of the problems on image classification. The data in each class is not equal and has a relatively large difference generated in less than optimal classification results. Ideally, the data in each class is equal or have a slight difference. This article discusses the classification of the histopathology breast cancer image. The data consist of 8 classes with unbalanced data. The method for balancing the data in each class uses random resampling which is applied to training data only. The data used from BreakHist with magnifications of 40x, 100x, 200x, and 400x . The classification uses Residual Network (ResNet) 18 and 50. The best results are obtained on images with a magnification of 400x. Classification results using ResNet18 has an average accuracy of $79.82 \%$, an average precision of $71.39 \%$, and an average recall of $82.37 \%$. Meanwhile using ResNet50 showed an average accuracy of $81.67 \%$, average precision of $78.41 \%$, and an average recall of $82.91 \%$.
\end{abstract}

Keywords : Histopathology; Breast Cancer; Random Resampling Data; Residual Network; Image Classification.

\begin{abstract}
Abstrak
Ketidakseimbangan data antar kelas merupakan salah satu permasalahan yang dihadapi pada klasifikasi citra. Jumlah data pada tiap kelas yang tidak sama serta memiliki selisih yang relatif besar mengakibatkan hasil klasifikasi kurang optimal. Idealnya jumlah data pada tiap kelas sama ataupun selisih data tidak jauh berbeda. Pada artikel ini dibahas tentang klasifikasi citra hispatologi kanker payudara. Data ujicoba menggunakan 8 kelas dengan data tidak seimbang. Metode untuk menyeimbangkan data pada tiap kelas menggunakan random resampling yang diterapkan pada data training saja. Ujicoba menggunakan citra histopatologi kanker payudara dari BreakHist dengan perbesaran 40x, 100x, 200x, dan 400x. Klasifikasi menggunakan Residual Network (ResNet) 18 dan 50. Hasil ujicoba terbaik didapatkan pada citra dengan perbesaran 400x. Saat menggunakan ResNet18 tercapai akurasi rata-rata $79,82 \%$, precision rata-rata $71,39 \%$, dan recall rata-rata $82,37 \%$. Sedangkan ujicoba menggunakan ResNet50 menunjukkan akurasi rata-rata 81,67\%, precision rata-rata 78,41\%, dan recall rata-rata $82,91 \%$.
\end{abstract}

Kata Kunci: Histopatologi; Kanker Payudara; Data Resampling Random; Residual Network; Klasifikasi Citra.

\section{Pendahuluan}

Kanker merupakan penyakit yang disebabkan oleh ketidaknormalan pembelahan sel-sel dalam tubuh. Kanker dapat menyerang seluruh jaringan pada tubuh. Salah satu jenis kanker dengan penderita tertinggi di Indonesia yaitu kanker payudara. Data dari Global Cancer Observatory dari Badan Kesehatan Dunia (WHO) menyebutkan pada tahun 2018 terjadi 58.256 kasus yang setara dengan 16,7\% dari keseluruhan kasus kanker di dunia. Rata-rata kematian yaitu 17 orang per 100 ribu penduduk.

Sedangkan untuk jumlah penderita kanker payudara di dunia 2,1 juta perempuan, dengan kasus kematian sebesar 627.000 atau sekitar 15\% (American

\footnotetext{
*) Penulis korespondensi: wsetiawan@ trunojoyo.ac.id
}

Cancer Society, 2019; Kementrian Kesehatan RI, 2016; World Health Organization, 2014).

Salah satu jenis pemeriksaan kanker yaitu biopsi dengan melakukan pengambilan sampel jaringan yang dicurigai terdapat sel kanker. Sampel jaringan tersebut selanjutnya dilakukan pemeriksaan di laboratorium untuk melihat karakteristiknya. Pemeriksaan jaringan menggunakan mikroskop untuk mengetahui sel kanker yang terdapat pada jaringan sekaligus menentukan grading dari kanker payudara. Selanjutnya, rekomendasi pengobatan dapat dilakukan setelah hasil biopsi didapatkan. Pemeriksaan jaringan yang berhubungan dengan penyakit disebut histopatologi. (Elston \& Ellis, 2002; Gurcan et al., 2009; Hilbertina, 2015). Untuk 
melakukan pemeriksaan laboratorium terhadap jaringan histopatologi payudara merupakan pekerjaan yang rumit, perlu ketelitian tinggi serta memakan waktu. Alternatif permasalahan tersebut dengan medical imaging melalui Computer Aided Diagnosis (CAD) System (Cruz-roa, Basavanhally, Gonz, Gilmore, \& Feldman, 2014; Kumar, Kumar, Saxena, \& Lakshmanan, 2020; Matos, Jr, Oliveira, \& Koerich, 2019).

Pada penelitian ini dilakukan klasifikasi citra histopathologi kanker payudara 2 kelas utama yaitu benign dan malignant. Benign merupakan tumor dengan pertumbuhan lambat dan terlokalisasi, sedangkan malignant merupakan kanker, melakukan invasi dan merusak struktur yang terhubung. Malignant dapat bersifat invasif secara lokal dan menyebar hingga menyebabkan kematian. Kelas utama memiliki 4 sub-kelas, jadi total sub-kelas yaitu 8. Pada jaringan payudara dapat diklasifikasi 4 kelas benign yaitu adenosis, fibroadenoma, phyllodestumor, tubular-adenoma. Sedangkan untuk 4 kelas malignant diantaranya ductal-carcinoma, lobularcarcinoma, muxinous-carcinoma dan papillarycarcinoma (Spanhol, Oliveira, Petitjean, \& Heutte, 2016).

Data yang digunakan untuk ujicoba yaitu BreakHist dan IDC. Data ini memiliki ketidakseimbangan jumlah data pada tiap kelas. Ketidakseimbangan data dapat mengakibatkan klasifikasi kurang optimal. Umumnya data yang digunakan untuk klasifikasi, tiap kelas memiliki data yang sama atau paling tidak memiliki selisih yang relatif sedikit. Namun jika data yang dimiliki kurang mendukung, maka dilakukan perbaikan terhadap jumlah data.

Penelitian tentang ketidakseimbangan data menggunakan citra histopatologi diantaranya yaitu klasifikasi citra kanker payudara menggunakan data IDC (Invasive Ductal Carcinoma) dan BreakHist dengan metode CNN (Convolutional Neural Network). Arsitektur yang digunakan GoogleNet. Augmentasi data menggunakan flip vertikal, translasi 20 piksel dan rotasi $-90^{\circ}$ dan $90^{\circ}$. Hasil ujicoba menunjukkan akurasi 94,1\% (perbesaran citra 40x), 93,2\% (perbesaran citra 100x), 94,7\% (perbesaran citra 200x) dan 93,5\% (perbesaran citra 400x) (Han et al., 2017).

Selanjutnya terdapat penelitian menggunakan data tidak seimbang dari IDC dan BreakHist. Citra IDC terdiri dari 277.524 patches berukuran 50x50 piksel. Terdiri dari 2 kelas dengan prosentase patches negatif $71.61 \%$ dan patches positif $28.39 \%$. Metode penyeimbangan data menggunakan SMOTE (Synthetic Minority Over-sampling Technique). Klasifikasi menggunakan CNN yang memiliki arsitektur terdiri dari 2 Convolutional Layer, 2 ReLU, 1 max-pooling, 2 Fully Connected Layer, Drop-Out (0.25 dan 0.5) dan softmax. Ujicoba menghasilkan akurasi $85,48 \%$ untuk data dari IDC sedangkan
BreakHist menghasilkan akurasi 85,62\%. (Reza \& Ma, 2018).

Penelitian selanjutnya tentang unbalance data menggunakan metode Synthetic Minority Over Sampling Technique (SMOTE). Data yang digunakan dari Colorectal Cancer histopatology Dataset. Jumlah data 5000 citra berukuran $150 \times 150$ piksel. Terdapat 8 kelas citra. Arsitektur yang digunakan yaitu MobileNet. Hasil akurasi dari ujicoba dengan single majority $91,67 \%$ dan single minority 93,27\% (Koziarski, 2020).

Penelitian sebelumnya umumnya menggunakan metode SMOTE untuk menyeimbangkan jumlah data. Sedangkan untuk metode klasifikasi menggunakan arsitektur CNN seperti GoogleNet (Szegedy et al., 2015), MobileNet (Howard et al., 2017) serta arsitektur modifikasi CNN lainnya. Penelitianpenelitian yang telah dilakukan belum memperoleh hasil yang optimal. Selain itu beragamnya model arsitektur CNN yang digunakan pada setiap penelitian, menyulitkan untuk dilakukan perbandingan hasil penelitian. Oleh karena itu pada artikel ini terdapat kebaruan, yaitu pertama, menerapkan metode random resampling pada data training dengan variasi ujicoba jumlah kelas. Kedua, menggunakan arsitektur CNN ResNet18 dan ResNet50 dengan variabel data pre-trained network bernilai sama sehingga dapat dilakukan perbandingan. Ketiga, hasil klasifikasi dengan random resampling dilakukan perbandingan dengan hasil klasifikasi dengan unbalanced data.

\section{Kerangka Teori}

Pada bagian ini dibahas tentang data BreakHist, IDC, metode untuk menyeimbangkan data menggunakan random-resampling, CNN ResNet18 dan ResNet 50 sebagai metode klasifikasi serta confusion matrix untuk menghitung akurasi, precision dan recall.

\subsection{Data}

\subsubsection{BreakHist}

Data ujicoba menggunakan Breast Cancer Histopathological Database (BreakHis). Data terdiri dari 9.109 citra jaringan tumor payudara dari 82 pasien menggunakan perbesaran 40x, 100x, 200x dan 400x. Data total terdiri dari 2.480 citra tumor jinak dan 5.429 citra tumor ganas atau kanker berukuran 700x460 piksel, RGB 8 bit, berformat PNG. Dataset ini merupakan hasil kolaborasi P\&D laboratory dan Pathological Anatomy and Chitopatology, Parana, Brasil. Data dapat diakses melalui https://web.inf.ufpr.br/vri/databases/breast-cancerhistopathological-database-breakhis/. Jumlah sebaran data citra ditunjukkan pada Tabel 1 (Spanhol et al., 2016). 
Tabel 1. Jumlah sebaran data citra BreakHist

\begin{tabular}{ccccc}
\hline Kelas & \multicolumn{4}{c}{ Perbesaran } \\
\cline { 2 - 5 } & $40 \mathrm{X}$ & $100 \mathrm{X}$ & $200 \mathrm{X}$ & $400 \mathrm{X}$ \\
\hline A & 114 & 113 & 111 & 106 \\
FA & 253 & 260 & 264 & 237 \\
PT & 109 & 70 & 108 & 115 \\
TA & 149 & 150 & 140 & 130 \\
DC & 864 & 903 & 896 & 788 \\
LC & 156 & 170 & 163 & 137 \\
MC & 205 & 222 & 196 & 169 \\
PC & 145 & 142 & 135 & 138 \\
\hline
\end{tabular}

Berikut ini merupakan definisi dari 8 kelas pada dataset BreakHist (Dumitru et al., 2015; Kuijper, Mommers, Wall, \& Diest, 2001; Spanhol et al., 2016; Zakaria \& Ahmed, 2016):

1. Adenosis (A) merupakan tumor jinak dengan ciri saluran lobules (kelenjar yang memproduksi susu) membesar, terdapat lebih banyak kelenjar daripada biasanya. Adenosis sering ditemukan pada pemeriksaan biopsi pada wanita yang memiliki gangguan fibrosis dan kista pada payudara .

2. Fibroadenoma (FA) merupakan berbagai macam benjolan/padatan yang menyebabkan tumor jinak, umumnya terjadi saat pra-menopause pada wanita ada usia 20-an tahun. Fibroadenoma membawa resiko sangat kecil untuk terjadinya kanker payudara.

3. Phyllodes_tumor (PT) merupakan jenis tumor yang sangat jarang terjadi. Secara statistik, jumlah kejadian tumor ini kurang dari $1 \%$. Phyllodes diambil dari bahasa Yunani yang berarti "seperti daun". Tumor ini dapat tumbuh cepat, namun jarang menyebar keluar area payudara.

4. Tubular_adenoma (TA) merupakan tumor jinak pada payudara berupa padatan yang menyerupai tabung dan kuncup formasi sel. Munculnya dapat bersama dengan ciri fibroadenoma. Tumor ini tumbuh lambat pada jaringan di payudara.

5. Ductal_carcinoma (DC) merupakan kanker yang tumbuh pada saluran susu dan berkembang pada jaringan lemak atau fibrous di luar jaringan susu. Jenis kanker ini umum terjadi pada penderita kanker payudara dengan diagnosis penderita lebih dari $80 \%$.

6. Lobular_carcinoma (LC) merupakan kanker yang awal mulanya terjadi pada kelenjar yang memproduksi susu (lobuler) pada payudara. Kanker ini dapat menyebabkan kerusakan pada lobule dan berpotensi untuk menyebar ke kelenjar getah bening dan area tubuh lainnya.

7. Mucinous_carcinoma (MC) merupakan tipe kanker payudara dengan tumor payudara yang tidak umum yaitu munculnya extracellular mucin. Kanker ini terjadi 1 hingga $7 \%$ dari semua penderita kanker payudara

8. Papillary_carcinoma (PC) merupakan jenis 1kanker dengan bentuk seperti jari tangan saat terlihat dengan mikroskop pada pemeriksaan hasil biopsi. Tampilan data ujicoba citra histopatologi kanker payudara ditunjukkan pada Gambar 1.

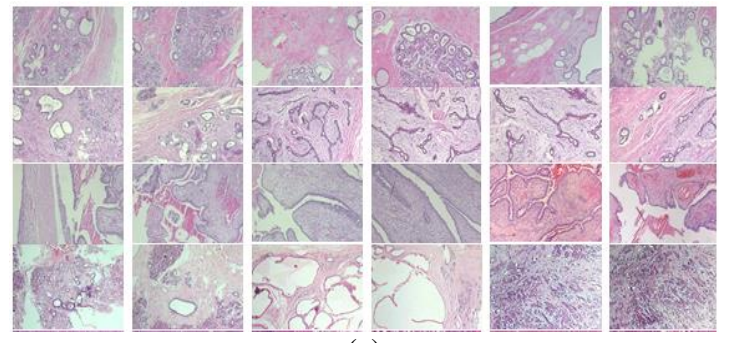

(a)

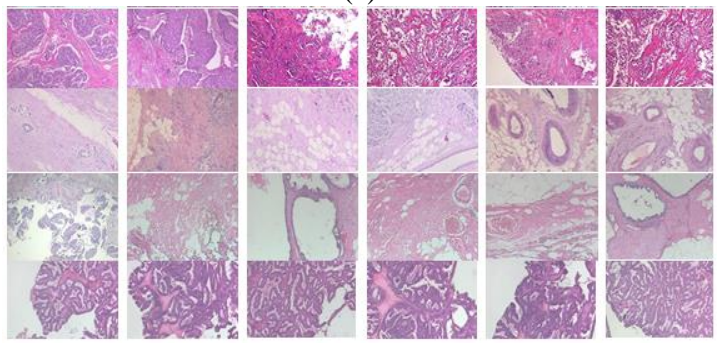

(b)

Gambar 1. Jaringan payudara

(a) Benign (b) Malignant (Spanhol et al., 2016)

\subsubsection{Invasive Ductal-Carcinoma (IDC)}

Sebagai pembanding digunakan data dari Invasive Ductal-Carcinoma (IDC) dataset, jenis kanker ini merupakan yang paling sering dijumpai pada kanker payudara. Hasil citra dari foto pemeriksaan biopsi difokuskan pada region yang mengandung IDC.

Awalnya dataset IDC terdiri dari 162 citra histopatologi kanker payudara yang mengalami perbesaran 40x. Selanjutnya dilakukan ekstraksi untuk mendapatkan 277. 524 patches dengan ukuran 50x50 piksel ( 198.738 IDC negatif, dan 78.786 IDC positif) (Cruz-roa et al., 2014; Janowczyk \& Madabhushi, 2016)

\subsection{Random Resampling}

Data ujicoba BreakHist memiliki sebaran yang tidak merata, mulai 109 hingga 864 tiap kelasnya. Jumlah data citra yang tidak merata di tiap kelasnya tersebut dapat diberikan solusi dengan melakukan resampling data secara random. Resampling memiliki 2 tipe yaitu oversampling dan undersampling. Random Oversampling merupakan teknik sederhana yang melakukan duplikasi secara random dari data yang terdapat pada minority class. Sedangkan Random undersampling yaitu melakukan penghapusan data secara random yang terdapat pada majority kelas, yaitu kelas yang memiliki data besar. Tujuan dari resampling yaitu data training yang digunakan sama pada setiap kelas.

Konsep random resampling juga disebut sebagai "naïve resampling" karena tidak ada asumsi apapun tentang data dan tidak ada tahapan yang digunakan (no-heuristic). Resampling hanya digunakan untuk data training. Data testing tetap menggunakan data awal tanpa modifikasi. Kekurangan dari metode ini biasanya terjadi saat proses undersampling. 
Kemungkinan terjadinya penghapusan data yang justru berguna sebagai penentu fitur terbaik untuk proses klasifikasi. Untuk itu diperlukan validasi data agar dapat digunakan pada random undersampling untuk mencari model terbaik (Chawla, Bowyer, \& Hall, 2002; H. He \& Garcia, 2009).

\subsection{Residual Network}

Residual Network memiliki beberapa model arsitektur yaitu ResNet18, 34, 50, 101 dan 152. Pada artikel ini hanya digunakan arsitektur ResNet18 dan ResNet50 sebagai pembanding. Ciri dari ResNet yaitu penggunaan kembali (re-use) output dari layer-layer sebelumnya. Konsep dari Resnet ditunjukkan pada Gambar 2. ResNet merupakan pemenang pada ImageNet Large Scale Visual Recognition Competition (ILSVRC) pada tahun 2015. ResNet 18 memiliki convolutional layer dengan filter berukuran $7 \times 7$ di awal layer, $3 \times 3$ di sebagian besar convolutional layer dan filter $1 \times 1$. Selain itu terdapat Batch normalization dan ReLU sebagaimana terdapat pada Gambar 3 (K. He \& Sun, 2015).
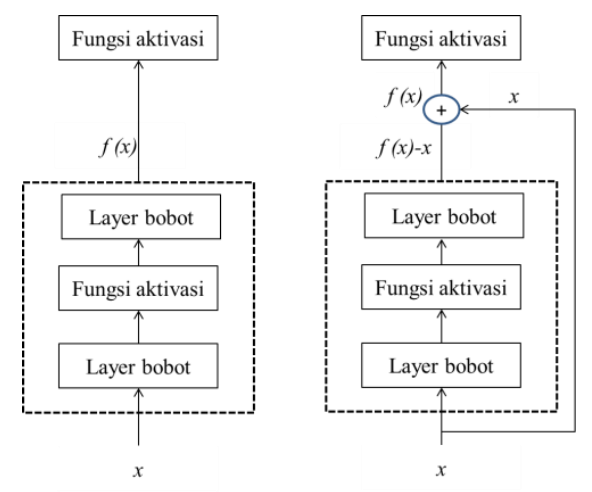

Gambar 2. Blok reguler vs blok residual

\subsubsection{Residual Network18}

ResNet18 merupakan arsitektur CNN Residual Network dengan jumlah kedalaman layer 18. Jumlah 18 dihitung dari jumlah convolutional layer dengan filter $7 \times 7$ berjumlah 1 layer, $3 \times 3$ berjumlah 16 layer serta $3 \times 3$ max-pooling layer. Convolutional layer memiliki ukuran filter $7 \times 7$ berjumlah 1 layer, $3 \times 3$ berjumlah 16 layer, dan $1 \times 1$ berjumlah 3 layer. Jadi ResNet18 memiliki total 20 convolutional layer. Pada setiap convolutional layer terdapat Batch Normalization dan ReLU. Di bagian akhir layer ekstraksi fitur terdapat Global Average Pooling. Sedangkan layer klasifikasi memiliki Fully Connected layer dan Softmax sebagai aktivasi (K. He, Zhang, Ren, \& Sun, 2015).
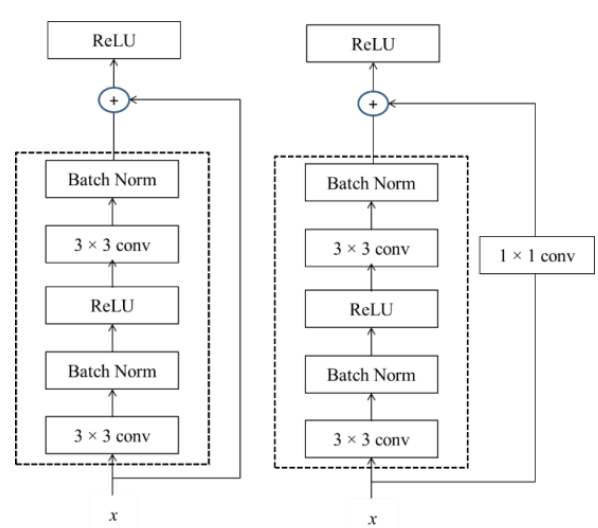

Gambar 3. ResNet tanpa dan dengan Conv $1 \times 1$

\subsubsection{Residual Network50}

ResNet50 sesuai dengan namanya memiliki kedalaman layer 50 yang didapatkan dari convolutional layer dengan filter $3 \times 3$ dan $1 \times 1$ dengan total berjumlah 48 layer, ditambah dengan convolutional layer dengan filter $7 \times 7$ berjumlah 1 layer, serta $3 \times 3$ max-pooling layer. Pada bagian akhir layer ekstraksi fitur dan layer klasifikasi sama dengan ResNet18 yaitu Global Average Pooling, Fully Connected layer dan softmax. Untuk lebih jelasnya perbedaan antara ResNet18 dan ResNet50 ditunjukkan pada Tabel 2 (K. He et al., 2015).

Tabel 2. Layer pada ResNet18 dan ResNet50

\begin{tabular}{|c|c|c|c|c|}
\hline $\begin{array}{l}\text { Nama } \\
\text { Layer }\end{array}$ & $\begin{array}{l}\text { Ukuran } \\
\text { output }\end{array}$ & 18-layer & 50-layer & \\
\hline Conv1 & $112 \times 112$ & \multicolumn{3}{|c|}{$\begin{array}{c}7 \times 7,64, \text { stride } 2 \\
3 \times 3 \text { max pool, stride } 2\end{array}$} \\
\hline Conv2_x & $56 \times 56$ & {$\left[\begin{array}{l}3 \times 3,64 \\
3 \times 3,64\end{array}\right] \times 2$} & {$\left[\begin{array}{c}1 \times 1,64 \\
3 \times 3,64 \\
1 \times 1,256\end{array}\right]$} & $\times 2$ \\
\hline Conv2_x & $28 \times 28$ & {$\left[\begin{array}{l}3 \times 3,128 \\
3 \times 3,128\end{array}\right] \times 2$} & {$\left[\begin{array}{l}1 \times 1,128 \\
3 \times 3,128 \\
1 \times 1,512\end{array}\right]$} & $\times 2$ \\
\hline Conv2_x & $14 \times 14$ & {$\left[\begin{array}{l}3 \times 3,256 \\
3 \times 3,256\end{array}\right] \times 2$} & {$\left[\begin{array}{c}1 \times 1,256 \\
3 \times 3,256 \\
1 \times 1,1024\end{array}\right]$} & $\times 2$ \\
\hline Conv2_x & $7 \times 7$ & {$\left[\begin{array}{l}3 \times 3,512 \\
3 \times 3,512\end{array}\right] \times 2$} & {$\left[\begin{array}{c}1 \times 1,512 \\
3 \times 3,512 \\
1 \times 1,2048\end{array}\right]$} & $\times 2$ \\
\hline & $1 \times 1$ & avg_pool, FCL & $\max$ & \\
\hline
\end{tabular}

\subsection{Confusion Matrix}

Confusion matrix merupakan standar untuk mendapatkan perhitungan performance measure dari akurasi, precision dan recall. Pada Gambar 4 ditunjukkan confusion matrix dari 3 kelas. Baris menunjukkan aktual, sedangkan kolom menunjukkan hasil prediksi. Perhitungan akurasi, precision dan recall ditunjukkan pada formula (1) hingga (9) (Theodoridis \& Koutroumbas, 2003). 


\begin{tabular}{|c|c|c|c|c|}
\hline & \multicolumn{4}{|c|}{ PREDICTED } \\
\hline $\mathrm{A}$ & & $\mathrm{A}$ & $\mathrm{B}$ & $\mathrm{C}$ \\
$\mathrm{C}$ & & & \\
$\mathrm{T}$ & $\mathrm{A}$ & $\mathrm{TP}_{\mathrm{A}}$ & $\mathrm{E}_{\mathrm{AB}}$ & $\mathrm{E}_{\mathrm{AC}}$ \\
$\mathrm{U}$ & & & & \\
$\mathrm{A}$ & $\mathrm{B}$ & $\mathrm{E}_{\mathrm{BA}}$ & $\mathrm{TP}_{\mathrm{B}}$ & $\mathrm{E}_{\mathrm{BC}}$ \\
$\mathrm{L}$ & $\mathrm{C}$ & $\mathrm{E}$ & $\mathrm{E}$ & $\mathrm{E}$ \\
\cline { 2 - 5 } & & & & \\
\hline
\end{tabular}

Gambar 4. Confusion Matrix 3 kelas

$$
\begin{gathered}
\text { Precision }=\text { Prec. } A+\text { Prec. } B+\text { Prec. } C \\
\text { Prec. } A=\frac{T P_{A}}{\left(T P_{A}+E_{B A}+E_{C A}\right)} \\
\text { Prec. } B=\frac{T P_{B}}{\left(T P_{B}+E_{A B}+E_{C B}\right)} \\
\text { Prec. } C=\frac{T P_{C}}{\left(T P_{C}+E_{A C}+E_{B C}\right)}
\end{gathered}
$$

\section{Metode}

Tahapan dari penelitian ini ditunjukkan oleh blok diagram pada Gambar 5. Data ujicoba dibagi menjadi 2 bagian yaitu data training dan data testing. Pada data training dilakukan random resampling. Kelas dengan jumlah data kecil akan melakukan oversampling yaitu menambah data secara random agar sama dengan kelas lainnya. Untuk kelas dengan jumlah data besar akan melakukan undersampling yaitu mengurangi jumlah data secara random pada kelasnya agar sama dengan kelas lainnya. Pemilihan data oversampling dan undersampling dilakukan secara "nä̈ve" yang memungkinkan data yang terpilih dapat lebih satu kali. Selanjutnya dilakukan proses klasifikasi menggunakan residual network. Tahap pelatihan menggunakan data training untuk menghasilkan model prediksi. Sedangkan hasil dari tahap pengujian dilakukan pengenalan sehingga dapat terklasifikasi dalam kelas tertentu.

Atribut yang terdapat pada arsitektur ResNet diantaranya menggunakan minibatch-size 64, optimasi stochastic gradient descent with momentum (SGDM), inisialisasi learning rate $3 \times 10^{-4}$. Perbandingan data training dan testing yaitu 80\%:20\%.

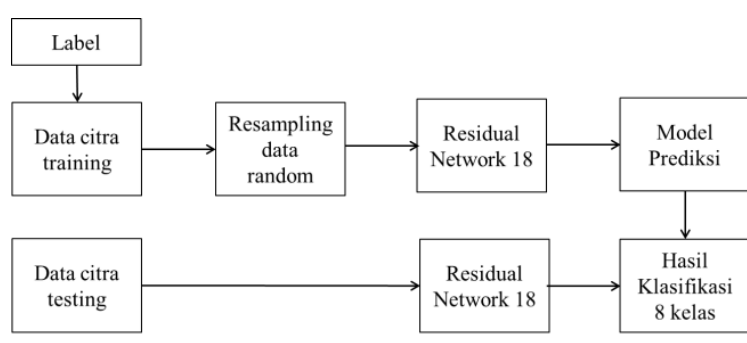

Gambar 5. Block diagram klasifikasi citra histopatologi kanker payudara dengan data random resampling

Untuk mengetahui kehandalan dari metode yang digunakan, dibuat skenario ujicoba sebagai berikut:

1. Ujicoba menggunakan data random resampling citra perbesaran 40x, 100x, 200x dan 400x dengan klasifikasi 2 hingga 8 kelas menggunakan ResNet18.

2. Ujicoba menggunakan data citra perbesaran yang sama denagn skenario 1. Klasifikasi dilakukan pada 2 hingga 8 kelas menggunakan ResNet18. Selanjutnya hasil pada skenario 1 dan 2 dihitung rata-rata nilai akurasi terbaik.

3. Data perbesaran citra dengan akurasi terbaik, selanjutnya dibandingkan dengan hasil klasifikasi menggunakan ResNet50 dengan atribut variabel yang sama dengan hasil ujicoba skenario 1 dan 2

4. Klasifikasi dengan data dari Invasive DuctalCarcinoma (IDC).

\section{Hasil dan Pembahasan}

\subsection{Hasil Ujicoba}

4.1.1. Hasil Pengujian Skenario 1

Pada Tabel 3 disajikan hasil pengujian menggunakan metode resampling secara random dengan perbesaran citra 40x hingga 400x.

Tabel 3. Hasil pengujian skenario 1

\begin{tabular}{cccc}
\hline \multicolumn{4}{c}{ Perbesaran citra 40x } \\
\hline $\begin{array}{c}\text { Jumlah } \\
\text { kelas }\end{array}$ & Akurasi (\%) & Presisi (\%) & Recall (\%) \\
\hline 2 & 98,97 & 99,43 & 95,45 \\
3 & 90,98 & 90,76 & 80,38 \\
4 & 74,17 & 79,72 & 73,33 \\
5 & 68,46 & 70,79 & 65,61 \\
6 & 68,64 & 62,03 & 68,64 \\
7 & 58,15 & 52,35 & 56,91 \\
8 & 56,57 & 54,17 & 62,75 \\
\hline Rata-rata & 73,71 & 72,75 & 71,87 \\
\hline \multicolumn{4}{c}{ Perbesaran citra 100x } \\
\hline 2 & 97,03 & 98,39 & 86,36 \\
3 & 93,7 & 84,51 & 82,75 \\
4 & 79,17 & 68,03 & 59,64 \\
5 & 74,83 & 57,37 & 56,00 \\
6 & 61,27 & 50,93 & 44,5 \\
7 & 62,98 & 43,52 & 50,62 \\
8 & 55,45 & 41,56 & 44,34 \\
\hline Rata-rata & 74,92 & 63,47 \\
\hline \multicolumn{4}{c}{}
\end{tabular}




\begin{tabular}{cccc}
\hline $\begin{array}{c}\text { Jumlah } \\
\text { kelas }\end{array}$ & Akurasi (\%) & Presisi (\%) & Recall (\%) \\
\hline 2 & 100 & 100 & 100 \\
3 & 88,19 & 71,62 & 68,68 \\
4 & 80,42 & 60,18 & 57,98 \\
5 & 74,68 & 56,19 & 62,51 \\
6 & 66,67 & 52,88 & 57,24 \\
7 & 64,36 & 59,31 & 69,02 \\
8 & 63,68 & 50,72 & 53,25 \\
\hline Rata-rata & 76,86 & 64,41 & 66,95 \\
\hline \multicolumn{4}{c}{ Perbesaran citra 400x } \\
\hline 2 & 95,56 & 92,59 & 85,73 \\
3 & 87,72 & 80,98 & 93,75 \\
4 & 83,59 & 75,01 & 86,98 \\
5 & 78,68 & 68,08 & 81,4 \\
6 & 81,41 & 74,77 & 97,79 \\
7 & 65,08 & 55,46 & 66,78 \\
8 & 66,67 & 52,87 & 64,18 \\
\hline Rata-rata & 79,82 & 71,39 & 82,37 \\
\hline
\end{tabular}

Hasil pengujian menunjukkan bahwa klasifikasi menggunakan data perbesaran citra 400X lebih baik dibandingkan dengan lainnya. Akurasi rata-rata mencapai $79,82 \%$, precision rata-rata $71,39 \%$ dan recall rata-rata $82,37 \%$.

\subsubsection{Hasil pengujian skenario 2}

Selanjutnya pada Tabel 4 merupakan hasil dari pengujian skenario 2 .

Tabel 4. Hasil pengujian skenario 2

\begin{tabular}{cccc}
\hline \multicolumn{4}{c}{ Perbesaran citra 40x } \\
\hline $\begin{array}{c}\text { Jumlah } \\
\text { kelas }\end{array}$ & Akurasi $(\%)$ & Presisi $(\%)$ & Recall $(\%)$ \\
\hline 2 & 96,91 & 98,32 & 86,36 \\
3 & 86,88 & 87,83 & 65,09 \\
4 & 76,67 & 84,33 & 66,71 \\
5 & 72,48 & 70,72 & 72,06 \\
6 & 66,86 & 60,89 & 54,4 \\
7 & 66,48 & 58,99 & 50,27 \\
8 & 54,54 & 45,75 & 57,28 \\
\hline Rata-rata & 74,40 & 72,40 & 64,60 \\
\hline \multicolumn{4}{c}{ Perbesaran citra 100x } \\
\hline 2 & 100 & 100 & 100 \\
3 & 92,13 & 84,18 & 78,44 \\
4 & 85,11 & 75,49 & 66,6 \\
5 & 74,83 & 50,52 & 48,01 \\
6 & 73,41 & 57,87 & 44,34 \\
7 & 61,36 & 38,31 & 41,6 \\
8 & 52,47 & 42,21 & 36,91 \\
\hline Rata-rata & 77,04 & 64,08 & 59,41 \\
\hline \multicolumn{4}{c}{ Perbesaran citra 200x } \\
\hline 2 & 100 & 100 & 100 \\
3 & 88,19 & 71,62 & 68,68 \\
4 & 80,42 & 60,18 & 57,98 \\
5 & 74,68 & 56,19 & 62,51 \\
\hline 6 & 66,67 & 52,88 & 57,24 \\
7 & 64,36 & 59,31 & 69,02 \\
8 & 63,68 & 50,72 & 53,25 \\
\hline Rata-rata & 78,03 & 69,95 & 69,25 \\
\hline \multicolumn{4}{c}{}
\end{tabular}

\begin{tabular}{cccc}
\hline \multicolumn{4}{c}{ Perbesaran citra 400x } \\
\hline $\begin{array}{c}\text { Jumlah } \\
\text { kelas }\end{array}$ & Akurasi (\%) & Presisi (\%) & Recall (\%) \\
\hline 2 & 97,78 & 98,77 & 90,91 \\
3 & 87,72 & 87,28 & 64,14 \\
4 & 85,17 & 78,85 & 85,86 \\
5 & 78,42 & 69,72 & 85,86 \\
6 & 76,92 & 72,62 & 82,68 \\
7 & 74,56 & 68,07 & 74,04 \\
8 & 55,19 & 47,43 & 46,07 \\
\hline Rata-rata & 79,39 & 74,68 & 75,65 \\
\hline
\end{tabular}

Hasil pengujian terbaik tanpa random resampling juga terdapat pada data ujicoba citra dengan perbesaran 400X. Pada skenario 2 menghasilkan akurasi rata-rata $79,39 \%$, precision rata-rata $74,68 \%$ dan recall rata-rata $75,65 \%$.

\subsubsection{Hasil pengujian pada skenario 3}

Pengujian skenario 3 menggunakan klasifikasi ResNet50. Data ujicoba dengan citra perbesaran 400X. hasil ujicoba ditunjukkan pada Tabel 5.

Tabel 5. Hasil pengujian menggunakan ResNet50

\begin{tabular}{cccc}
\hline \multicolumn{4}{c}{ Perbesaran citra 400x dengan Resampling } \\
\hline $\begin{array}{c}\text { Jumlah } \\
\text { kelas }\end{array}$ & Akurasi (\%) & Presisi (\%) & Recall (\%) \\
\hline 2 & 96,67 & 98,17 & 86,36 \\
3 & 89,47 & 83,82 & 97,92 \\
4 & 84,38 & 86,15 & 79,56 \\
5 & 79,86 & 71,49 & 91,59 \\
6 & 80,77 & 79,26 & 88,24 \\
7 & 72,78 & 68,84 & 70,09 \\
8 & 67,76 & 61,15 & 66,61 \\
\hline Rata-rata & 81,67 & 78,41 & 82,91 \\
\hline \multicolumn{4}{c}{ Perbesaran citra 400x tanpa Resampling } \\
\hline 2 & 97,78 & 98,77 & 90,9 \\
3 & 88,6 & 83,14 & 95,83 \\
4 & 83,59 & 76,84 & 79,14 \\
5 & 77,70 & 69,33 & 87,40 \\
6 & 76,92 & 74,42 & 79,63 \\
7 & 69,23 & 65,55 & 65,01 \\
8 & 67,76 & 60,17 & 64,36 \\
\hline Rata-rata & 80,23 & 75,46 & 80,32 \\
\hline
\end{tabular}

Hasil klasifikasi menggunakan ResNet50 dengan data perbesaran 400x menunjukkan bahwa akurasi rata-rata terbaik didapatkan dengan ujicoba menggunakan data dengan resampling random. Namun selisih keduanya tidak signifikan.

\subsubsection{Hasil ujicoba skenario 4}

Klasifikasi pada skenario 4 menggunakan data dari Invasive Ductal-Carcinoma. Namun karena keterbatasan dari spesifikasi device yang digunakan, data ujicoba terbatas pada 10 folder pertama. Data ujicoba meliputi 8.044 citra non-IDC dan 1.727 citra IDC. Nilai inisialisasi variabel dibuat sama dengan 3 skenario sebelumnya. Hasil dari ujicoba skenario 4 ditunjukkan pada Tabel 6 . 
Tabel 6. Hasil ujicoba dari skenario 4

\begin{tabular}{ccccc}
\hline $\begin{array}{c}\text { Arsitektur } \\
\text { CNN }\end{array}$ & \multicolumn{3}{c}{ Perbesaran citra 400x dengan Resampling } \\
\hline & $\begin{array}{c}\text { Jumlah } \\
\text { kelas }\end{array}$ & $\begin{array}{c}\text { Akurasi } \\
(\%)\end{array}$ & $\begin{array}{c}\text { Presisi } \\
(\%)\end{array}$ & $\begin{array}{c}\text { Recall } \\
(\%)\end{array}$ \\
\hline ResNet50 & 2 & 83,62 & 72,12 & 73,19 \\
ResNet18 & 2 & 85,06 & 74,35 & 73,00 \\
\hline
\end{tabular}

Hasil ujicoba dengan data resampling random menggunakan ResNet50 menghasilkan jumlah citra perkelas 6.435 dengan akurasi 83,62\%, presisi 72,12\% dan Recall 73,19\%. Sedangkan untuk ResNet18 masing-masing akurasi, presicion dan recall yaitu $85,06 \%, 74,35 \%$ dan $73 \%$.

\subsection{Pembahasan}

Penggunaan metode resampling random dengan data BreakHist dilakukan untuk perbaikan data. Jumlah data tidak terlalu jauh berbeda kecuali pada kelas Ductal_Carcinoma. Hasil data resampling secara random memberikan jumlah data otomatis yang digunakan sebagai data ujicoba. Setiap kelas menghasilkan jumlah data yang sama. Pada Tabel 7 ditunjukkan jumlah data hasil resampling pada masing-masing skenario perbesaran citra.

Tabel 7. Jumlah data ujicoba hasil resampling

\begin{tabular}{cc}
\hline Perbesaran & Jumlah data per-kelas \\
\hline $40 \mathrm{X}$ & 691 \\
$100 \mathrm{X}$ & 722 \\
$200 \mathrm{X}$ & 717 \\
$400 \mathrm{X}$ & 630 \\
\hline
\end{tabular}

Jumlah data yang sama pada setiap kelas dapat meningkatkan prosentase akurasi pada masing-masing data dengan perbesaran citra 40x, 100x, 200x, dan 400x.

Untuk metode klasifikasi CNN menunjukkan bahwa akurasi lebih baik pada saat sistem menggunakan jumlah layer yang lebih banyak. Sistem menghasilkan lebih banyak fitur saat diproses menggunakan ResNet50 dibandingkan dengan ResNet18.

Untuk penggunaan nilai variabel pada pre-trained network memberikan pengaruh terhadap hasil klasifikasi. Nilai inisialisasi learning rate, jumlah epoch dan metode optimasi menentukan tingkat keberhasilan klasifikasi dari sistem.

Perbandingan hasil klasifikasi lainnya yaitu dengan menggunakan dataset dari IDC. Jumlah data unbalanced yang besar yaitu kelas non-IDC 8.044 citra, kelas IDC 1.727 citra. Total terdapat 9.771 dengan jumlah data ujicoba perkelas mencapai 6.435 (setelah dilakukan random resampling). Hasil ujicoba skenario 4 menunjukkan bahwa ResNet18 lebih baik jika dibandingkan dengan ResNet50 saat diterapkan pada klasifikasi data menggunakan dataset IDC sebagaimana ditunjukkan pada Tabel 6.

\section{Kesimpulan}

Pada artikel ini telah dilakukan ujicoba menggunakan resampling data secara random. Klasifikasi menggunakan ResNet18 dan ResNet50. Hasil ujicoba menunjukkan penggunaan data BreakHist dan IDC. Perbedaan hasil akurasi antara random resampling dan tanpa random resampling tidak signifikan. Selisih akurasi antara penggunaan metode resampling dan tanpa resampling hanya $\pm 1 \%$.

Dari semua skenario ujicoba didapatkan bahwa metode random resampling dapat diterapkan dengan baik pada klasifikasi dengan jumlah kelas kecil (antara 2 hingga 5 kelas), namun untuk jumlah kelas yang lebih besar (antara 6 hingga 8 kelas) hasil klasifikasi kurang.

Untuk tahapan berikutnya dapat dilakukan perbandingan dengan ResNet34, ResNet101 dan ResNet152 ataupun dengan jenis arsitektur CNN lain untuk meningkatkan hasil pengujian sistem. Selain itu dapat digunakan metode resampling data SMOTE dengan harapan hasil pengukuran dapat lebih baik dibandingkan dengan penelitian yang telah dilakukan. Pada bagian akhir dari sistem dapat dilakukan validasi menggunakan $k$-fold Cross validation untuk membuktikan bahwa kehandalan metode yang diterapkan.

\section{Daftar Pustaka}

American Cancer Society, 2019. Breast Cancer Facts \& Figures 2019-2020.

Chawla, N.V, Bowyer, K. W., \& Hall, L. O., 2002. SMOTE: Synthetic Minority Over-sampling Technique. Journal of Artifial Intelligence Research, 16, 321-357.

Cruz-roa, A., Basavanhally, A., Gonz, F., Gilmore, H., \& Feldman, M., 2014. Automatic detection of invasive ductal carcinoma in whole slide images with Convolutional Neural Networks. In Medical Imaging 2014 : Digital Pathology (Vol. 9041, pp. 1-15). https://doi.org/10.1117/12.2043872

Dumitru, A., Procop, A., Iliesiu, A., Tampa, M., Mitrache, L., Costache, M., ... Cirstoiu, M., 2015. Mucinous Breast Cancer: a Review Study of 5 Year Experience from a Hospital-Based Series of Cases. Medica, 10(1), 14-18.

Elston, C. W., \& Ellis, I. O., 2002. Pathological prognostic factors in breast cancer. I . The value of histological grade in breast cancer: experience from a large. Histopathology, 41, 151-153.

Gurcan, M. N., Boucheron, L., Can, Al., Madabhushi, A., Rajpoot, N., \& Yener, B., 2009. Histopathological Image ANalysis: A Review. IEEE Rev Biomed Eng, 2, 147-171. https://doi.org/10.1109/RBME.2009.2034865.His topathological 
Han, Z., Wei, B., Zheng, Y., Yin, Y., Li, K., \& Li, S., 2017. Breast Cancer Multi-classification from Histopathological Images with Structured Deep Learning Model. Scientific Reports, 7(May), 1-10. https://doi.org/10.1038/s41598-017-04075-Z

He, H., \& Garcia, E. A., 2009. Learning from Imbalanced Data. IEEE Transactions on Knowledge and Data Engineering, 21(9), 12631284.

He, K., \& Sun, J., 2015. Deep Residual Learning for Image Recognition. IEEE Xplore, 1-9. Retrieved from https://arxiv.org/abs/1512.03385

He, K., Zhang, X., Ren, S., \& Sun, J., 2015. Delving Deep into Rectifiers: Surpassing Human-Level Performance on ImageNet Classification. Retrieved from https://arxiv.org/abs/1502.01852

Hilbertina, N., 2015. Peranan patologi dalam diagnostik tumor payudara. Majalah Kedokteran Andalas, 38(1), 1-8.

Howard, A. G., Zhu, M., Chen, B., Kalenichenko, D., Wang, W., Weyand, T., Adam, H., 2017. MobileNets: Efficient Convolutional Neural Networks for Mobile Vision Applications Andrew.

Janowczyk, A., \& Madabhushi, A., 2016. Deep learning for digital pathology image analysis: A comprehensive tutorial with selected use cases. $J$ Pathol Inform, 7(29), 1-18. https://doi.org/10.4103/2153-3539.186902

Kementrian Kesehatan RI, 2016. infodatin kanker payudara 2016.pdf.

Koziarski, M., 2020. Two-Stage Resampling for Convolutional Neural Network Training in the Imbalanced Colorectal Cancer Image Classification, 1-15.

Kuijper, A., Mommers, E. C. M., Wall, E. Van Der, \& Diest, P. J. Van, 2001. Histopathology of Fibroadenoma of the Breast. Anatomic Pathology, $115,736-742$.
Kumar, A., Kumar, S., Saxena, S., \& Lakshmanan, K., 2020. Deep feature learning for histopathological image classification of canine mammary tumors and human breast cancer. Information Sciences, 508 , 405-421. https://doi.org/10.1016/j.ins.2019.08.072

Matos, J. De, Jr, A. D. S. B., Oliveira, L. E. S., \& Koerich, A. L., 2019. Double Transfer Learning for Breast Cancer Histopathologic Image Classification. 2019 International Joint Conference on Neural Networks (IJCNN), (July), $1-8$.

Reza, S., \& Ma, J., 2018. Imbalanced Histopathological Breast Cancer Image Classification with Convolutional Neural Network. 2018 14th IEEE International Conference on Signal Processing (ICSP), 619624.

Spanhol, F. A., Oliveira, L. S., Petitjean, C., \& Heutte, L., 2016. A Dataset for Breast Cancer Histopathological Image Classification. IEEE Transactions on Biomedical Engineering, 63(7), 1455-1462.

Szegedy, C., Liu, W., Jia, Y., Sermanet, P., Reed, S., Anguelov, D., ... Arbor, A., 2015. Going Deeper with Convolutions. In CVPR2015 (pp. 1-9). https://doi.org/10.1109/CVPR.2015.7298594

Theodoridis, S., \& Koutroumbas, K., 2003. Pattern Recognition (Second Edi). San Diego, California: Elsevier.

World Health Organization, 2014. WHO Position paper on mammography screening.

Zakaria, F., \& Ahmed, S., 2016. Histological variations in fibroadenoma of breast. Histological Variations in Fibroadenoma of Breast, 7(11), 760-764. https://doi.org/10.7439/ijbr 